\title{
Histone Methyltransferase Inhibition Has a Cytotoxic Impact on Transformed Mast Cells: Implications for Mastocytosis
}

\author{
SULTAN ALANAZI ${ }^{1}$, FABIO RABELO MELO $^{1}$ and GUNNAR PEJLER ${ }^{1,2}$ \\ ${ }^{1}$ Uppsala University, Department of Medical Biochemistry and Microbiology, Uppsala, Sweden; \\ ${ }^{2}$ Swedish University of Agricultural Sciences, Department of Anatomy, \\ Physiology and Biochemistry, Uppsala, Sweden
}

\begin{abstract}
Background/Aim: Mast cell transformation, as manifested in mastocytosis, can be a serious condition for which there are limited therapeutic options. Mastocytosis cells can be sensitive to histone deacetylase (HDAC) inhibitors, but their sensitivity to other histone-modifying enzymes has not been assessed. Here we addressed this issue. Materials and Methods: Inhibitors of histone methyl transferases, histone demethylases, histone acetyl transferases and HDACs were tested for their effects on growth, viability, caspase-3 activation and annexin V/DRAQ7 staining in transformed mast cells. Results: Transformed mast cells underwent cell death in response to histone methyl transferase and HDAC inhibition, but were not sensitive to histone demethylase or histone acetyl transferase inhibition. Histone methyl transferase inhibition led to cell death with characteristics of apoptosis, as judged by caspase-3 activation. However, DNA fragmentation was not apparent and Annexin $V^{+} / D R A Q 7^{-}$ cells were not predominant, suggesting a type of cell death differing from classical apoptosis. Conclusion: Histone methyl transferase inhibition could be developed as a novel regimen for targeting mastocytosis.
\end{abstract}

Mast cells are hematopoietic cells with a characteristic abundance of highly electron-dense secretory granules that contain large amounts of various bioactive substances such as histamine, cytokines, proteoglycans of serglycin type and different proteases $(1,2)$. Mast cells have a large impact on

This article is freely accessible online.

Correspondence to: Fabio R. Melo, Uppsala University, Department of Medical Biochemistry and Microbiology, Uppsala, Sweden. Tel: +46 18672104, e-mail: Fabio.Melo@imbim.uu.se; Gunnar Pejler, Uppsala University, Department of Medical Biochemistry and Microbiology, BMC, Box 582, 75123 Uppsala, Sweden. Tel: +46 184714571, e-mail: Gunnar.Pejler@imbim.uu.se

Key Words: Mast cells, mastocytosis, histones, demethylase, caspases. multiple immune-mediated responses including allergic conditions, and they have also been implicated in various additional pathologies such as arthritis and cancer (3).

Mastocytosis is a disease characterized by abnormal mast cell growth, and may be manifested in one or more tissues (4). In most cases, the abnormal mast cell growth is caused by mutations in KIT (predominantly KITD816V), i.e. the receptor for stem cell factor (SCF; the major growth factor for mast cells), such that the mast cells become independent of SCF for growth. Mastocytosis phenotypes span clinically from cutaneous to systemic variants, and the latter are subdivided into indolent, smoldering and aggressive forms, such as mast cell leukemia $(4,5)$. Mast cell leukemia is the most aggressive form of the systemic mastocytosis (SM) types, and this type of SM is characterized by bone marrow involvement (4-6). Organ damage is also observed in SM, and the overall survival time of the aggressive SM variants is often less than six months. Currently, there are only limited treatment options for SM, and allogeneic stem cell transplantation is currently emerging as a relatively promising therapeutic strategy (7). However, a large fraction of aggressive SM patients are found within the ageing population and these patients are frequently not suitable for stem cell transplantation (7). Treatment options are therefore largely limited to the symptoms, and there is no curative therapy (4-6).

Epigenetics comprise effects on gene expression that are manifested without altering DNA sequence, and encompass different mechanisms including DNA methylation, posttransitional modification (PTM) of core histones, and effects of non-coding RNAs (8, 9). PTMs of histones include methylation, acetylation, phosphorylation, and ubiquitination of their $\mathrm{N}$-terminal ends (10-13). Histone methylation often occurs at specific lysine or arginine residues at the $\mathrm{N}$ terminal portions that protrude out from the nucleosomes (14). Lysines can undergo either mono-, di- or trimethylation, while arginines can be either mono- or dimethylated (15). Histone methylation can either activate or repress transcription depending on the methylated residue 
and modification states (16). For example, transcriptional activation is associated with lysine methylation at $\mathrm{H} 3 \mathrm{~K} 4$, $\mathrm{H} 3 \mathrm{~K} 36$, and H3K79. On the contrary, gene repression is related to methylation at $\mathrm{H} 3 \mathrm{~K} 9, \mathrm{H} 3 \mathrm{~K} 27$ and H4K20 (17). The mechanisms underlying activating and repressing actions and how they work in a regulated manner is not fully understood (11-13).

Epigenetic modifications including DNA methylation and PTMs of histones are often perturbed in myeloid malignant diseases such as the myelodysplastic syndromes and myeloproliferative neoplasms (18). Mutations responsible for these diseases occur in several genes, and a number of point mutations in genes encoding epigenetic regulators (e.g., DNMT3A, EZH2, and TET2) have been observed in such malignancies, with implications for the progression, pathogenesis, and prognosis of these diseases $(19,20)$. Similar mutation patterns are also detected in $\operatorname{SM}(21,22)$ and increasing evidence suggests that a more thorough understanding of epigenetic modifications and the identification of gene mutations may help in predicting the development of aggressive disease phenotypes (23-26).

Inhibitors of epigenetic histone modifications, in particular histone deacetylase (HDAC) inhibitors, have previously been approved for some tumor subtypes, and a number of HDAC inhibitors are in clinical trials for the treatment of hematological and solid tumors (27). In line with this notion, previous studies have shown that inhibition of HDAC is cytotoxic for transformed mast cells (28), suggesting a therapeutic potential for HDAC inhibitors for the treatment of mastocytosis. However, it is not known if inhibition of histone-modifying enzymes beyond HDAC affects the growth of transformed mast cells. The purpose of this study was therefore to address this issue. Our findings reveal that transformed human mast cells, in addition to being sensitive to HDAC inhibition, are also sensitive to inhibition of histone methyl transferase activity. This may form the basis for a further assessment of histone methyl transferase inhibitors in the treatment of mast cell-related disorders such as mastocytosis.

\section{Materials and Methods}

Reagents. Anacardic acid and UNC-0638 were purchased from Sigma-Aldrich (Steinheim, Germany). UNC-1999 was from Selleckchem (Houston, TX, USA). Tranylcypromine hemisulfate, Daminozide and rabbit anti-H3K9me3 were from Active Motif (Carlsbad, CA, USA). Rabbit anti-H3K9me2 antibody was from EMD-Millipore (Darmstadt, Germany). Rabbit anti-H3K4me1 monoclonal antibody was from Cell Signaling Technology (Danvers, MA, USA). Rabbit anti-histone 2A (H2A), H2B, H3 and $\mathrm{H} 4$ antibodies, and mouse anti-H3K27me3 monoclonal antibody were from Abcam (Cambridge, UK). A mouse monoclonal antibody to $\beta$-actin was from Santa Cruz Biotechnology (Santa Cruz, CA, USA).
Culture of mast cell lines. The human mast cell line (HMC-1) was cultured in Iscove's Modified Dulbecco's medium (IMDM) supplemented with $10 \%$ heat-inactivated fetal bovine serum (FBS; Invitrogen, Carlsbad, CA, USA), $2 \mathrm{mM} \mathrm{L-glutamine} \mathrm{(Sigma}$ Aldrich), $100 \mu \mathrm{g} / \mathrm{ml}$ streptomycin (Sigma Aldrich), $100 \mathrm{IU} / \mathrm{ml}$ penicillin (Sigma Aldrich), and $1.2 \mathrm{mM}$ 1-thioglycerol (Sigma Aldrich). The LUVA human mast cell line was cultured in STEM PRO-34 SFM (Gibco, Waltham, MA, USA) supplemented with 2.6\% STEM PRO-34 nutrient supplement (Gibco), 10\% Heatinactivated fetal bovine serum, $2 \mathrm{mM} \mathrm{L}$-glutamine, $100 \mu \mathrm{g} / \mathrm{ml}$ streptomycin and $100 \mathrm{IU} / \mathrm{ml}$ penicillin. The medium was replaced every third day, and both cell lines were cultured at $0.33 \times 10^{6}$ cells $/ \mathrm{ml}$ at $37^{\circ} \mathrm{C}$ in $5 \% \mathrm{CO}_{2}$ atmosphere and used for at most 10 passages after initial thawing.

Cell viability assessment. To evaluate the effect of different inhibitors on cell viability, cells were preincubated with or without inhibitors. The Cell Titer-Blue cell viability assay (Promega-Invitrogen, Carlsbad, CA, USA) was used to assess cytotoxicity. Triplicates of $0.1 \times 10^{6}$ cells $/ \mathrm{ml}$ were resuspended in complete culture medium, transferred into a 24-well flat-bottomed plates and incubated overnight at $37^{\circ} \mathrm{C}$ in $5 \% \mathrm{CO}_{2}$ atmosphere. The next day, the cells were either treated with inhibitors or left non-treated, and incubated for different time periods. At various time points, $90 \mu \mathrm{l}$ of the cell suspensions were transferred into 96-well flat-bottomed plates, followed by adding $10 \mu \mathrm{l}$ of cell viability reagent. Following incubation for $1 \mathrm{~h}$ at $37^{\circ} \mathrm{C}\left(5 \% \mathrm{CO}_{2}\right)$ fluorescence was measured using a microplate reader (M200-TECAN Infinite; Tecan Austria GmbH, Grödig, Austria) at $560 \mathrm{~nm}$ for excitation and $590 \mathrm{~nm}$ for emission.

Flow cytometric assessment of cell death. Cells were treated with UNC-0638 $(5 \mu \mathrm{M}), \mathrm{UNC}-1999(5 \mu \mathrm{M})$, or left untreated prior to incubation for $24 \mathrm{~h}$ at $37^{\circ} \mathrm{C}$ in $5 \% \mathrm{CO}_{2}$ atmosphere. Subsequently, cells were centrifuged $(400 \times g / 5 \mathrm{~min})$, washed with cold PBS and assessed for necrotic/apoptotic cell death by staining with Annexin V (BD Biosciences, Franklin Lakes, NJ, USA) and DRAQ7 ${ }^{\mathrm{TM}}$ (Biostatus Ltd., Shepshed, UK) diluted in Annexin V binding buffer (BD Biosciences). The Annexin V-FITC apoptosis detection kit (BD Biosciences) was used according to the manufacturer's instructions. After $30 \mathrm{~min}$ incubation, stained cells were analyzed with BD Accuri $^{\mathrm{TM}}$ C6 Plus Flow Cytometer (BD Biosciences), and the FlowJo software (TreeStar Inc., Ashland, OR, USA) was used for data analysis. As a positive control for cell death, cells were incubated for $6 \mathrm{~h}$ with mefloquine $(10 \mu \mathrm{M})$. Cell numbers were quantified using Countess II, an automated cell counter (Thermo Fisher Scientific, Waltham, MA, USA).

Caspase-3 detection. Cells were treated with UNC-0638 (5 $\mu \mathrm{M})$, UNC$1999(5 \mu \mathrm{M})$, or non-treated prior to incubation for 2,6 or $24 \mathrm{~h}$. Subsequently, cells were centrifuged $(400 \times g / 5 \mathrm{~min})$, washed with cold PBS and resuspended in CellEvent Caspase 3/7 Detection Reagent (Invitrogen). The reagent was diluted in PBS (500 nM/300 $\mu 1 /$ sample), added to cells, and incubated for $30 \mathrm{~min}$. As a positive control, used for gate setting, cell death was induced by incubation of cells for $4 \mathrm{~h}$ with $0.75 \mathrm{mM}$ of $\mathrm{H}_{2} \mathrm{O}_{2}$ (Merck, Darmstadt, Germany).

Western blot. Western blot analysis was performed as previously described (29). Equal amounts of cells were lysed with $100 \mu \mathrm{l}$ of lysis buffer and boiled for $10 \mathrm{~min}$ at $95^{\circ} \mathrm{C}$ in a heating-block. Thereafter, samples were separated by SDS-polyacrylamide gel 
A

A

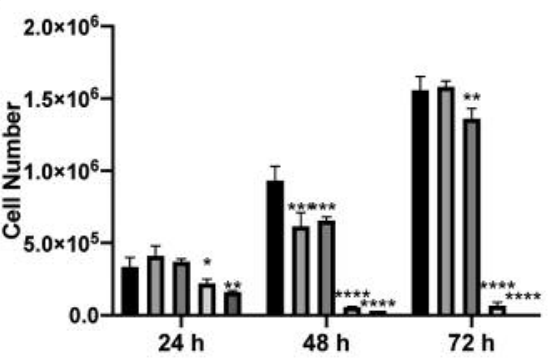

C

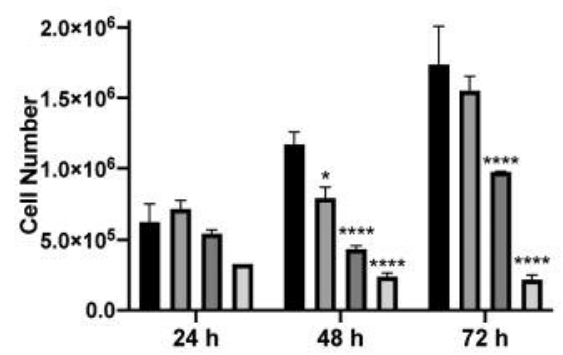

E

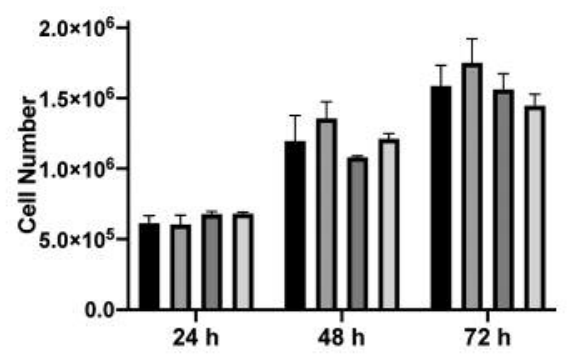

B

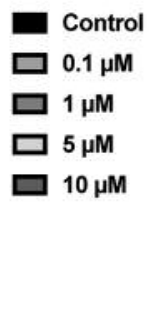

D

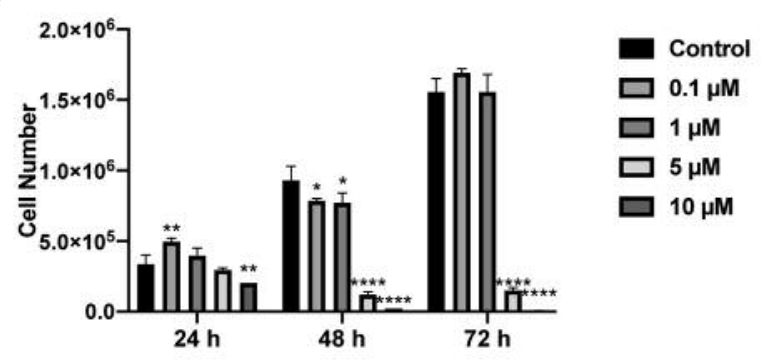

Anacardic acid

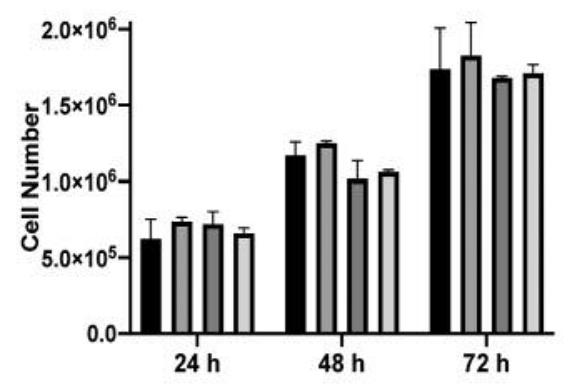

Control

$\square 25 \mathrm{nM}$

$\square 100 \mathrm{nM}$

$\square 500 \mathrm{nM}$

$\mathbf{F}$

Tranylcypromine Hemisulfate
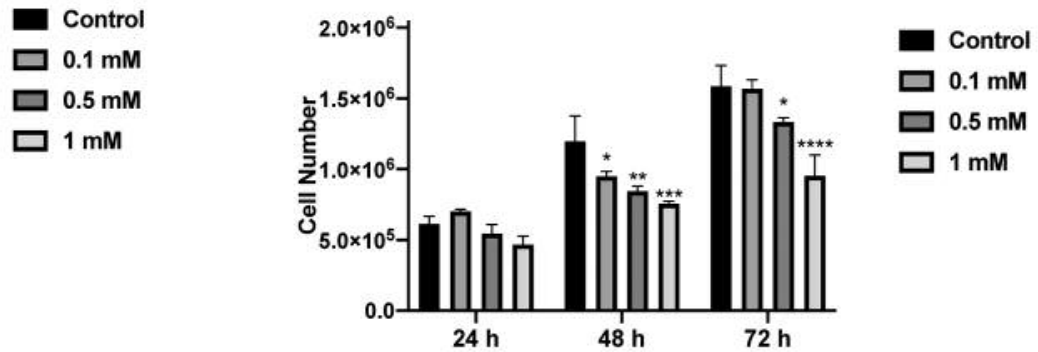

Figure 1. Histone methyltransferase inhibition reduces the growth of HMC-1 mast cells. HMC-1 cells $\left(0.1 \times 10^{6}\right.$ cells $\left./ \mathrm{ml}\right)$ were incubated with (A) UNC-0636 (histone methyltransferase inhibitor), (B) UNC-1999 (histone methyltransferase inhibitor), (C) trichostatin A (HDAC inhibitor), (D) anacardic acid (histone acetyltransferase inhibitor), $(E)$ diaminozide (methyl demethylase inhibitor) or $(F)$ trancylpromine hemisulfate (methyl demethylase inhibitor), at the indicated concentrations and time periods. Cell numbers were then quantified using an automated cell counter. Data are representative of three independent experiments and are given as mean values $\pm S E M(n=3) . * p \leq 0.05 ; * * p \leq 0.01 ; * * * p \leq 0.001 ; * * * * p \leq 0.0001$.

electrophoresis (Novex WedgeWell 4-20\% Tris-Glycine Gels, Thermo Fisher Scientific). Subsequently, the proteins were transferred onto Immobilon-FL PVDF membranes (EMDMillipore), followed by blocking in Odyssey Blocking buffer (LICOR, Lincoln, NE) mixed with an equal volume of TBS prior to overnight-incubation at $4{ }^{\circ} \mathrm{C}$ with one of the following primary antibodies (1:1000; in blocking buffer): Rabbit anti-H3K9me2 polyclonal antibody (EMD-Millipore), rabbit anti-H3K4me1 monoclonal antibody, rabbit anti-histone 3 (H3) polyclonal antibody, or mouse anti-H3K27me3 monoclonal. Thereafter, membranes were washed (3×10 min) with TBS/0.1\% Tween-20, and a final wash (10 min) with TBS was followed by incubation with secondary fluorescent antibodies $(1: 10,000$; in TBS or PBS). The secondary antibodies were from LI-COR (IRDye $800 \mathrm{CW}$ Donkey Anti-Rabbit IgG, IRDye $680 \mathrm{CW}$ Donkey Anti-Mouse IgG, and IRDye 800 Donkey; LI-COR). After one hour of incubation at room temperature, the membranes were washed again, then scanned by using the Odyssey CLx Imaging System (LI-COR). Western blots were quantified and analyzed using Fiji-ImageJ (developed by Wayne Rasband, National Institutes of Health). The targeted proteins were normalized to the loading control, $\beta$-actin or $\mathrm{H} 3$.

Statistical analysis. The statistical significance between groups was determined by using one-way ANOVA with post hoc Dunnett's or Tukey's multiple comparison test. All graphs were prepared, and statistics were calculated using GraphPad Prism 7.0 (GraphPad 
A

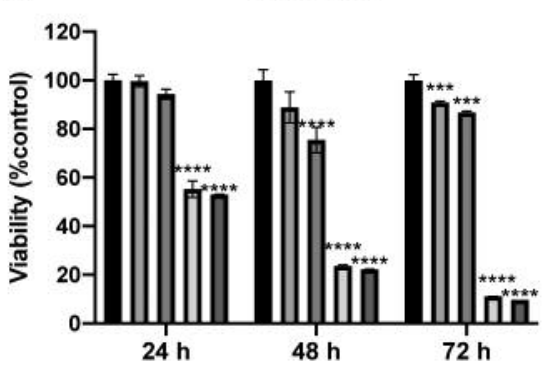

C

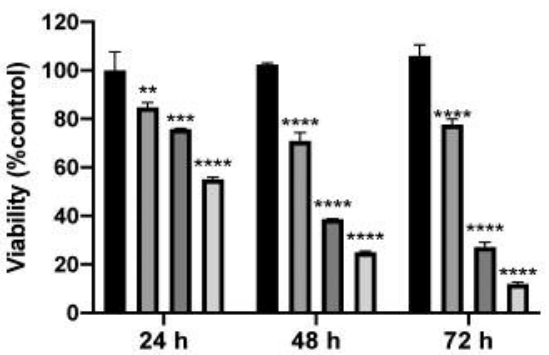

$\mathbf{E}$

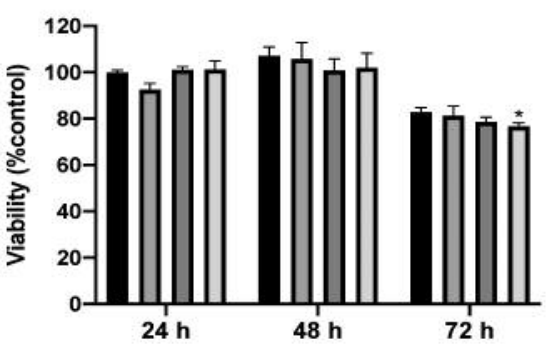

B

UNC-1999
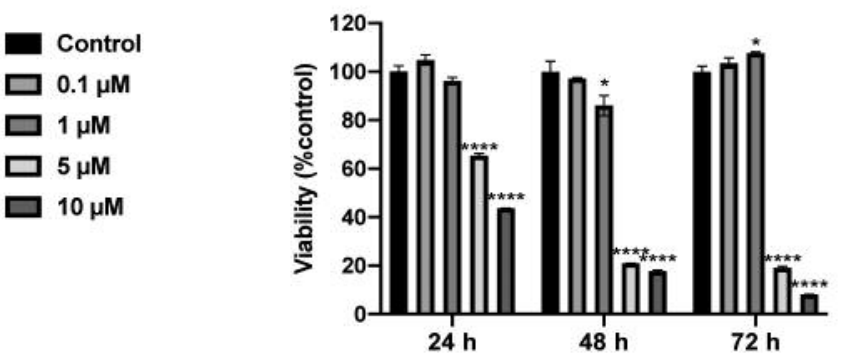

Control

$\square 0.1 \mu \mathrm{M}$

$\square 1 \mu \mathrm{M}$

$\square 5 \mu \mathrm{M}$

$\square 10 \mu \mathrm{M}$
D

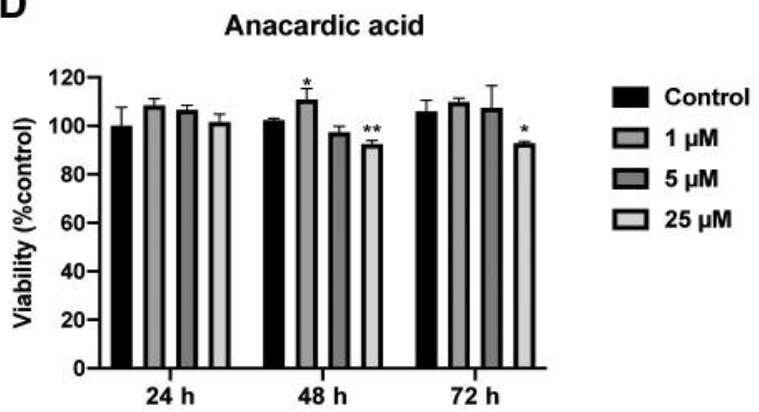

$\mathbf{F}$ Tranylcypromine Hemisulfate

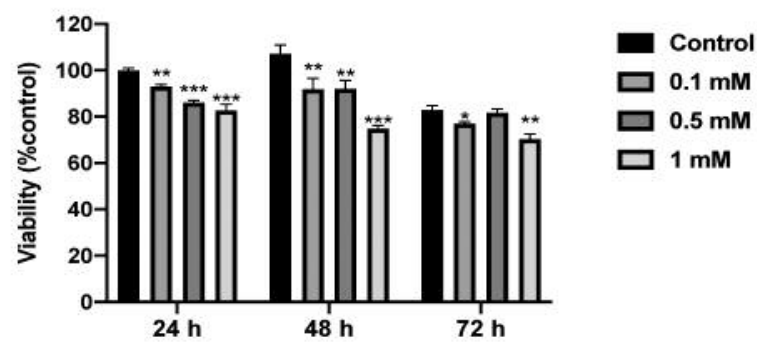

Figure 2. Histone methyltransferase inhibition reduces viability of HMC-1 mast cells. HMC-1 cells $\left(0.1 \times 10^{6}\right.$ cells/ml) were incubated with (A) UNC-0636 (histone methyltransferase inhibitor), (B) UNC-1999 (histone methyltransferase inhibitor), (C) trichostatin A (HDAC inhibitor), (D) anacardic acid (histone acetyltransferase inhibitor), $(E)$ diaminozide (methyl demethylase inhibitor) or $(F)$ trancylpromine hemisulfate (methyl demethylase inhibitor), at the indicated concentrations and time periods. Cell viability was then quantified using the CellTiter-Blue Cell Viability Assay. Data are representative of three independent experiments and are given as mean values $\pm S E M(n=3) .{ }^{*} p \leq 0.05 ; * * p \leq 0.01 ; * * * p \leq 0.001$; $* * * * p \leq 0.0001$.

software Inc., San Diego, CA, USA). A p-value of less than 0.05 was considered significant.

\section{Results}

Histone methyltransferase inhibitors decrease growth and viability of HMC-1 mast cells. HMC-1 mast cells were treated with various inhibitors of histone-modifying enzymes, followed by assessment of cell viability and growth. As shown in Figure 1A and B, both of the histone methyltransferase inhibitors (UNC-0638 and UNC-1999) inhibited HMC-1 mast cell growth in a time- and dose- dependent manner. In addition, trichostatin $\mathrm{A}$, an inhibitor of HDAC, also inhibited the growth of HMC-1 mast cells in a time- and dose-dependent manner (Figure 1C). In line with these findings, both of the histone methyltransferase inhibitors and trichostatin A caused profound reductions in HMC-1 cell viability, in a time- and dose-dependent manner (Figure 2C). In contrast, HMC-1 cells were relatively resistant to histone acetyl transferase inhibition (anacardic acid) or to blockade of histone demethylase activity (diaminozide or tranylcypromine hemisulfate), both with regard to cell growth (Figure 1D-F) and viability (Figure 2D-F). 

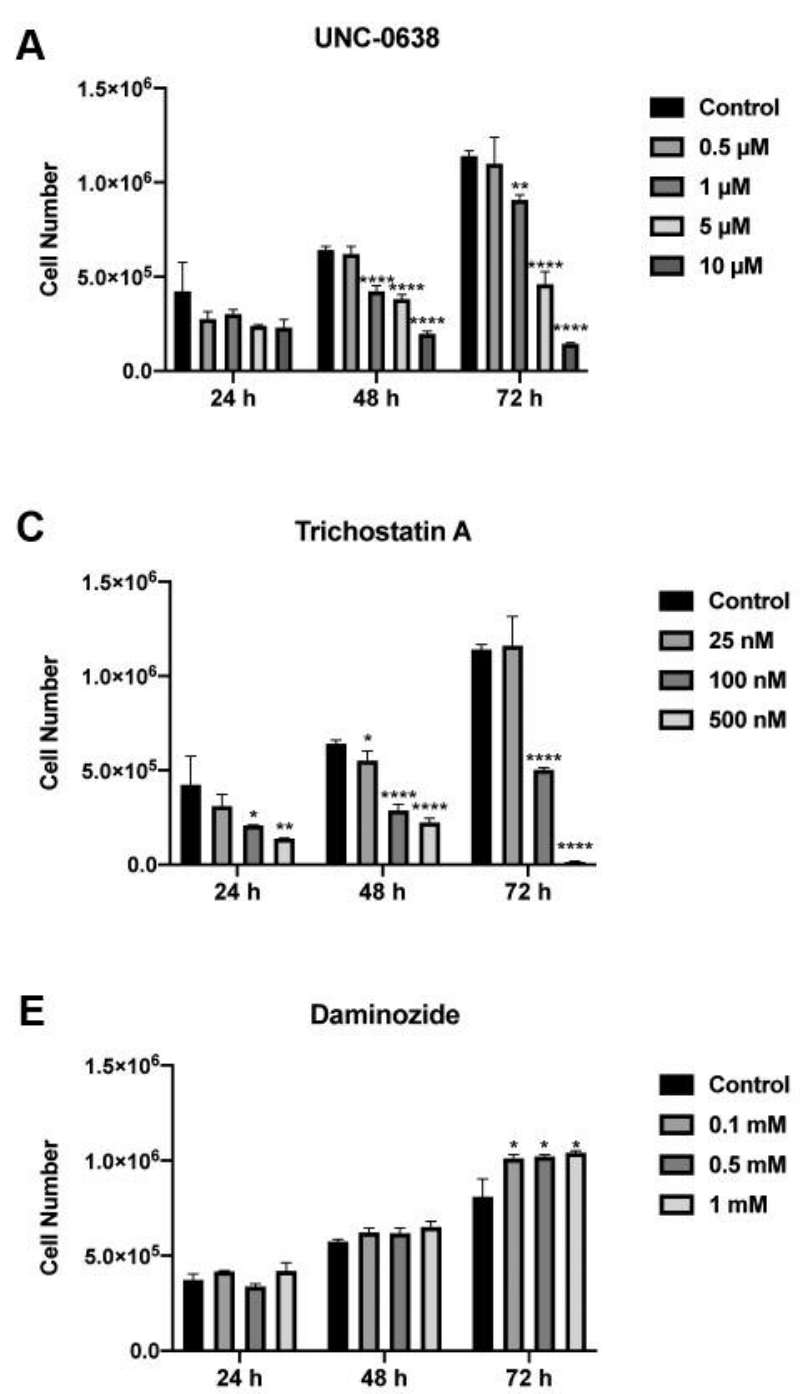
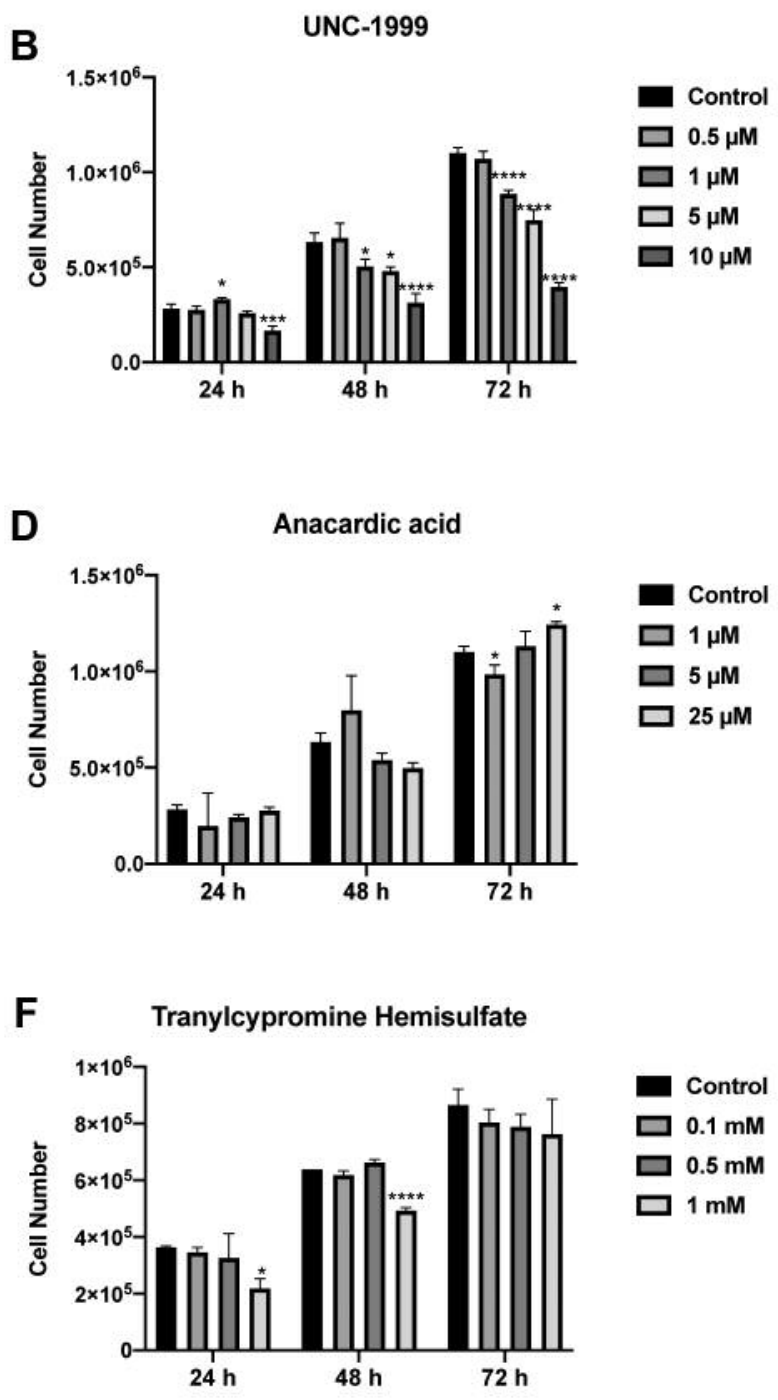

Figure 3. Histone methyltransferase inhibition reduces the growth of LUVA mast cells. LUVA cells $\left(0.1 \times 10^{6}\right.$ cells $/$ ml) were incubated with (A) UNC0636 (histone methyltransferase inhibitor), (B) UNC-1999 (histone methyltransferase inhibitor), (C) trichostatin A (HDAC inhibitor), (D) anacardic acid (histone acetyltransferase inhibitor), $(E)$ diaminozide (methyl demethylase inhibitor) or $(F)$ trancylpromine hemisulfate (methyl demethylase inhibitor), at the indicated concentrations and time periods. Cell numbers were then quantified using an automated cell counter. Data are representative of three independent experiments and are given as mean values $\pm S E M(n=3)$. *p $\leq 0.05 ; * * p \leq 0.01 ; * * * p \leq 0.001 ; * * * * p \leq 0.0001$.

LUVA mast cells are sensitive to treatment with histone methyltransferase inhibitors. The results above showed that HMC-1 mast cells are sensitive to histone methyltransferase inhibitors and to HDAC inhibition. In order to assess whether other populations of transformed mast cells were sensitive to such treatments, we also tested the effects of these compounds on LUVA mast cells. These analyses showed that LUVA mast cell were also sensitive to the inhibition of histone methyltransferase activity, both with respect to cell growth (Figure $3 \mathrm{~A}$ and $\mathrm{B}$ ) and viability (Figure 4A and B), although the effects were less pronounced in comparison with the HMC-1 cells. In further agreement with the effects observed on HMC-1 cells, the LUVA mast cells were also sensitive to HDAC inhibition (Figure 3C; Figure 4C) but essentially refractory to inhibition of histone methyltransferase or histone acetyl transferase activity (Figure 3D-F; Figure 4D-F).

Histone methyltransferase inhibitors induce caspase-3 activation in HMC-1 and LUVA mast cells. The findings above introduce the novel notion that transformed mast cells are sensitive to histone methyltransferase inhibitors, and confirm that such mast cell populations are sensitive to HDAC inhibition. Next, we focused on the effects of histone 
A

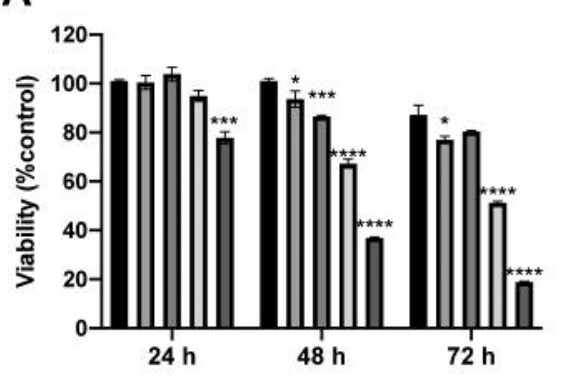

C

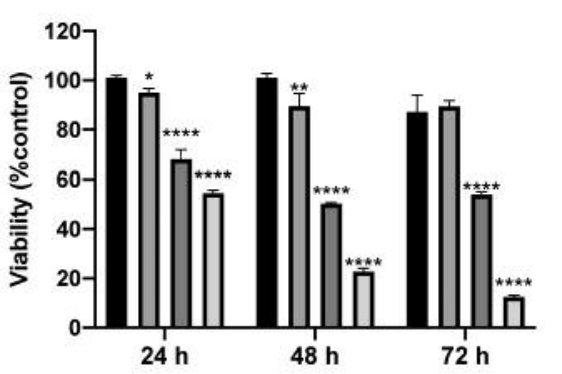

$\mathbf{E}$

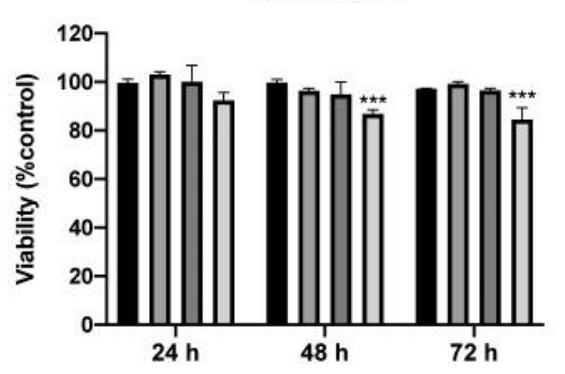

B

UNC-1999
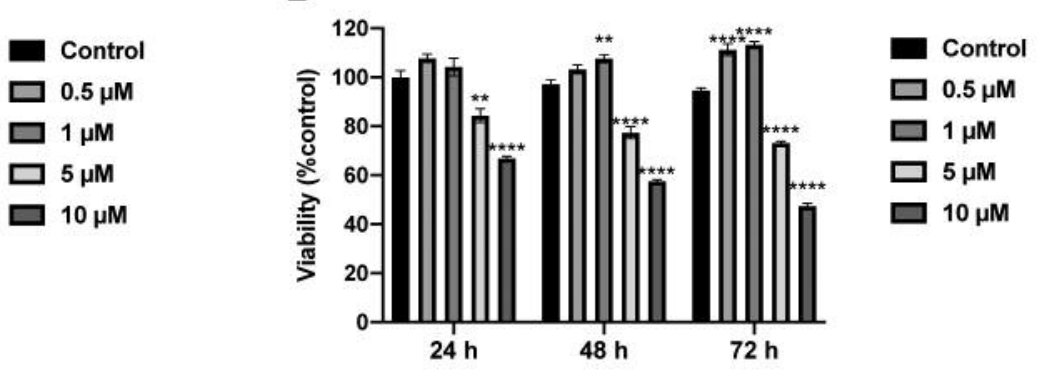

D

Anacardic Acid

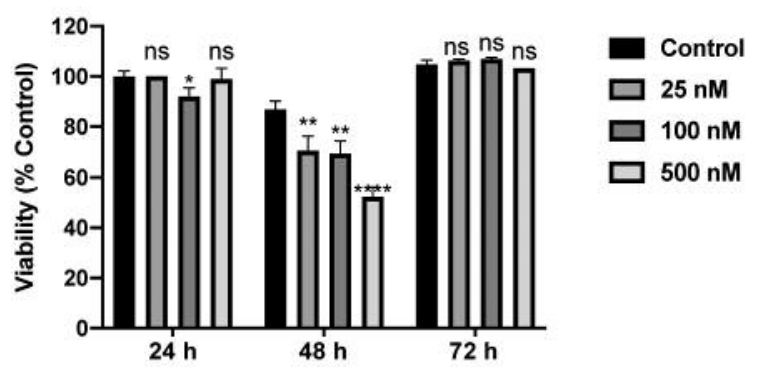

F Tranylcypromine Hemisulfate

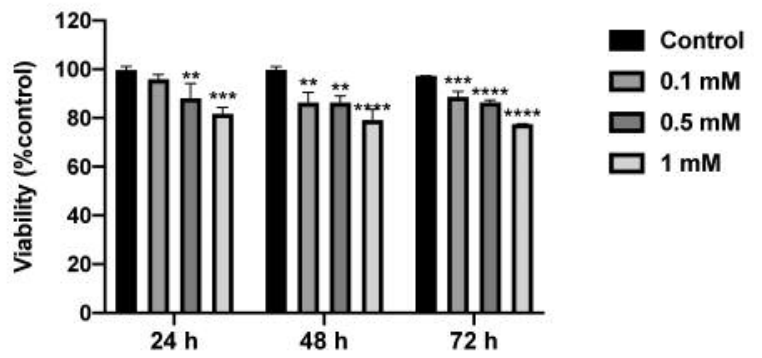

Figure 4. Histone methyltransferase inhibition reduces viability of LUVA mast cells. LUVA cells $\left(0.1 \times 10^{6}\right.$ cells/ml) were incubated with (A) UNC0636 (histone methyltransferase inhibitor), (B) UNC-1999 (histone methyltransferase inhibitor), (C) trichostatin A (HDAC inhibitor), (D) anacardic acid (histone acetyltransferase inhibitor), $(E)$ diaminozide (methyl demethylase inhibitor) or $(F)$ trancylpromine hemisulfate (methyl demethylase inhibitor), at the indicated concentrations and time periods. Cell viability was then quantified using the CellTiter-Blue Cell Viability Assay. Data are representative of three independent experiments and are given as mean values $\pm S E M(n=3) . * p \leq 0.05 ; * * p \leq 0.01 ; * * * p \leq 0.001 ; * * * * p \leq 0.0001$.

methyl transferase inhibition, with the aim of obtaining insight into the mechanism of cell death induced by this regimen. To approach this issue, we first assessed for activation of caspase-3. As shown in Figure 5A, the exposure of HMC-1 cells to both of the histone methyltransferase inhibitors (UNC-0638 and UNC-1999) caused activation of caspase- 3 , as measured by a flow cytometry-based approach. Notably, the kinetics of caspase-3 activation differed between the two inhibitors, with UNC-1999 causing a more rapid caspase- 3 activation than UNC-0638. Caspase-3 activation was also observed in LUVA cells subjected to histone methyltransferase inhibition, although the amplitude of caspase- 3 activation was not as high as that observed in the HMC-1 cells (Figure 6A).

Histone methyltransferase inhibitors do not induce DNA fragmentation in HMC-1 and LUVA mast cells. The induction of caspase-3 upon exposure to histone methyltransferase inhibition suggests cell death with characteristics of apoptosis. A hallmark feature of classical apoptosis is DNA fragmentation, induced by caspaseactivated DNAase. To assess whether the histone 
A $\quad \mathrm{HMC}-1$

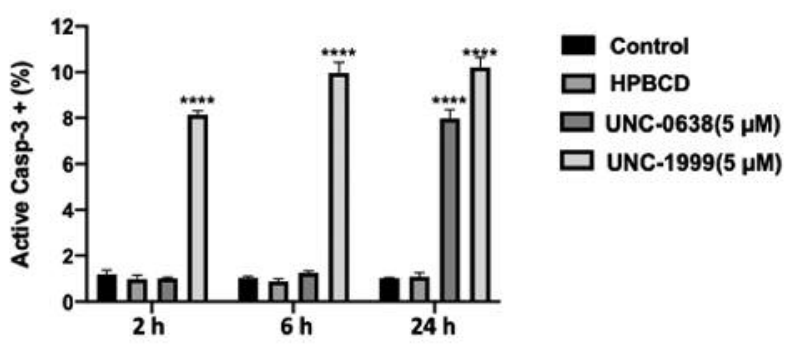

B

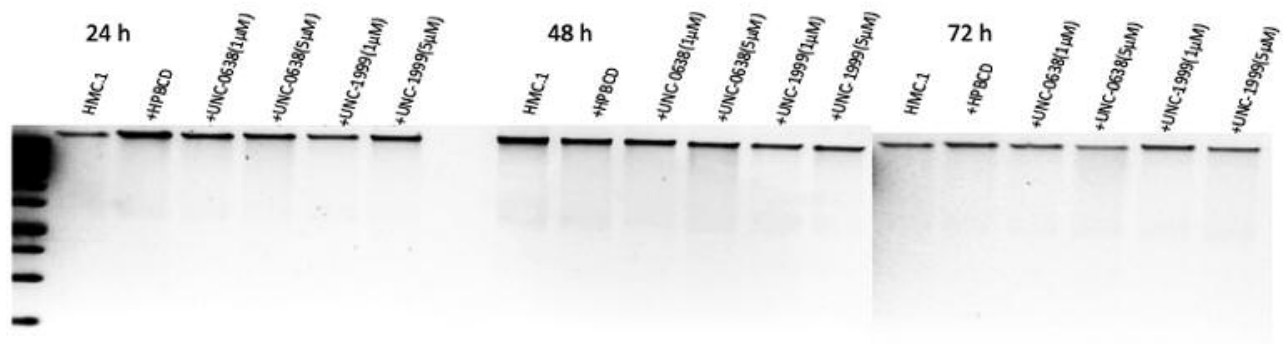

C
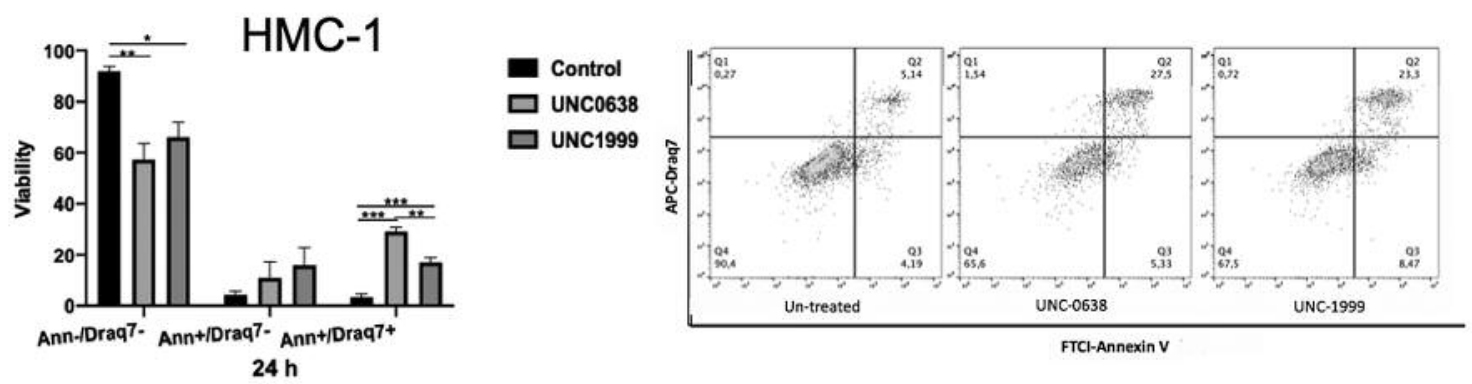

Figure 5. Histone methyltransferase inhibition causes caspase-3 activation and cell permeabilization but not DNA fragmentation in HMC-1 mast cells. HMC-1 cells $\left(0.1 \times 10^{6}\right.$ cells $\left./ \mathrm{ml}\right)$ were incubated with the histone methyltransferase inhibitors UNC-0638 (5 $\mu$ M) or UNC-1995 (5 $\mu$ M). (A) At the indicated time points, caspase-3 activity was measured using flow cytometry; HPBCD, 2-hydroxypropyl- $\beta$-cyclodextrin (vehicle control). (B) At the indicated time points, cell extracts were prepared and analyzed by agarose gel electrophoresis to detect DNA degradation/fragmentation. (C) HMC-1 cells were treated with methyltransferase inhibitors for $24 \mathrm{~h}$ and were analyzed by flow cytometry for Annexin V/DRAQ 7 positivity. Representative dot plots are shown to the right. Data are representative of three independent experiments and are given as mean values $\pm S E M(n=3) .{ }^{*} p \leq 0.05$; ** $p \leq 0.01$; $* * * p \leq 0.001 ; * * * * p \leq 0.0001$.

methyltransferase inhibitors induced DNA fragmentation, we analyzed extracts of treated cells by agarose gel electrophoresis. However, as depicted in the Figures. 5B and $6 \mathrm{~B}$, histone methyltransferase inhibition did not induce detectable DNA fragmentation, either in the HMC-1 or LUVA cells.

Histone methyltransferase inhibition induces membrane permeabilization in HMC-1 and LUVA mast cells. To further assess the mechanism of cell death in response to histone methyltransferase inhibition, we stained the cells with Annexin V (binds to phosphatidylserine) and DRAQ7 (nuclear dye). In classical apoptosis, Annexin V positivity is observed, indicative of phosphatidylserine translocation to the outer leaflet of the plasma membrane, whereas nuclear staining is absent (due to plasma membrane integrity). However, when the HMC-1 and LUVA cells were treated with either of the histone methyltransferase inhibitors, cells double positive for Annexin V and DRAQ7 predominated (Figure 5C and D, Figure 6C and D), arguing against a typical apoptotic death and suggesting that cells underwent cell death accompanied by cell membrane permeabilization. However, a small population of Annexin V+/DRAQ7- cells could also be detected, suggesting that classical apoptosis 
A

LUVA
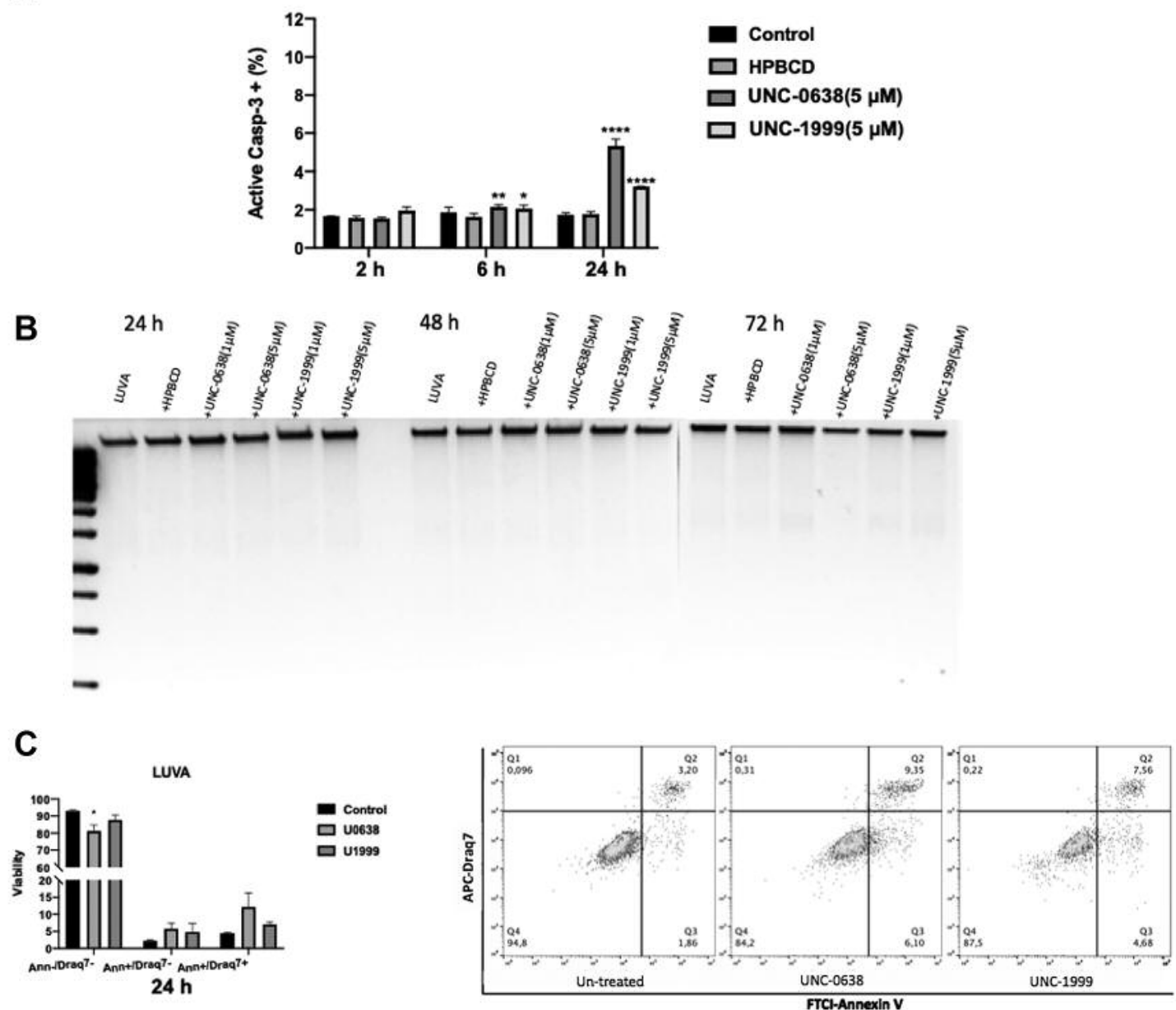

Figure 6. Histone methyltransferase inhibition causes caspase-3 activation and cell permeabilization but not DNA fragmentation in LUVA mast cells. LUVA cells $\left(0.1 \times 10^{6} \mathrm{cells} / \mathrm{ml}\right)$ were incubated with the histone methyltransferase inhibitors UNC-0638 (5 $\left.\mu M\right)$ or UNC-1995 (5 $\left.\mu M\right)$. (A) At the indicated time points, caspase-3 activity was measured using flow cytometry; HPBCD, vehicle control. (B) At the indicated time points, cell extracts were prepared and analyzed by agarose gel electrophoresis to detect DNA degradation/fragmentation. (C) LUVA cells were treated with methyltransferase inhibitors for $24 \mathrm{~h}$ and analyzed by flow cytometry for Annexin V/DRAQ 7 positivity. Representative dot plots are shown to the right. Data are representative of three independent experiments and are given as mean values $\pm S E M(n=3)$. ${ }^{*} p \leq 0.05 ; * * p \leq 0.01 ; * * * p \leq 0.0001$.

was also prevalent, although to a minor extent (Figure $5 \mathrm{C}$ and D, Figure 6C and D).

Histone methyltransferase inhibition decreases the H3K9me2 levels in HMC-1 cells and H3K27me3 in LUVA cells. Next, we used Western blot analysis to assess the ability of the histone methyltransferase inhibitors to block histone methylation, by focusing on selected histone marks: H3K9me2, H3K4me1, and H3K27me3. These experiments revealed that both inhibitors caused a significant reduction of the H3K9me 2 mark in HMC-1 cells, and this reduction persisted up to $24 \mathrm{~h}$ (Figure 7A-C). However, no significant impact on the $\mathrm{H} 3 \mathrm{~K} 9 \mathrm{me} 2$ mark was observed in LUVA cells (data not shown). Further, a small but significant reduction of the H2K27me3 mark was observed in LUVA cells after $24 \mathrm{~h}$ exposure to either of the histone methyltransferase inhibitors (Figure 7D-F). In contrast, no significant effects on $\mathrm{H} 2 \mathrm{~K} 27 \mathrm{me} 3$ were observed in $\mathrm{HMC}-1$ cells, and no significant effect of either of the histone methyltransferase inhibitors was observed on the levels of the H3K4me1 mark (data not shown).

\section{Discussion}

Mast cell activation and proliferation is partly controlled through SCF binding to the KIT tyrosine kinase receptor. 

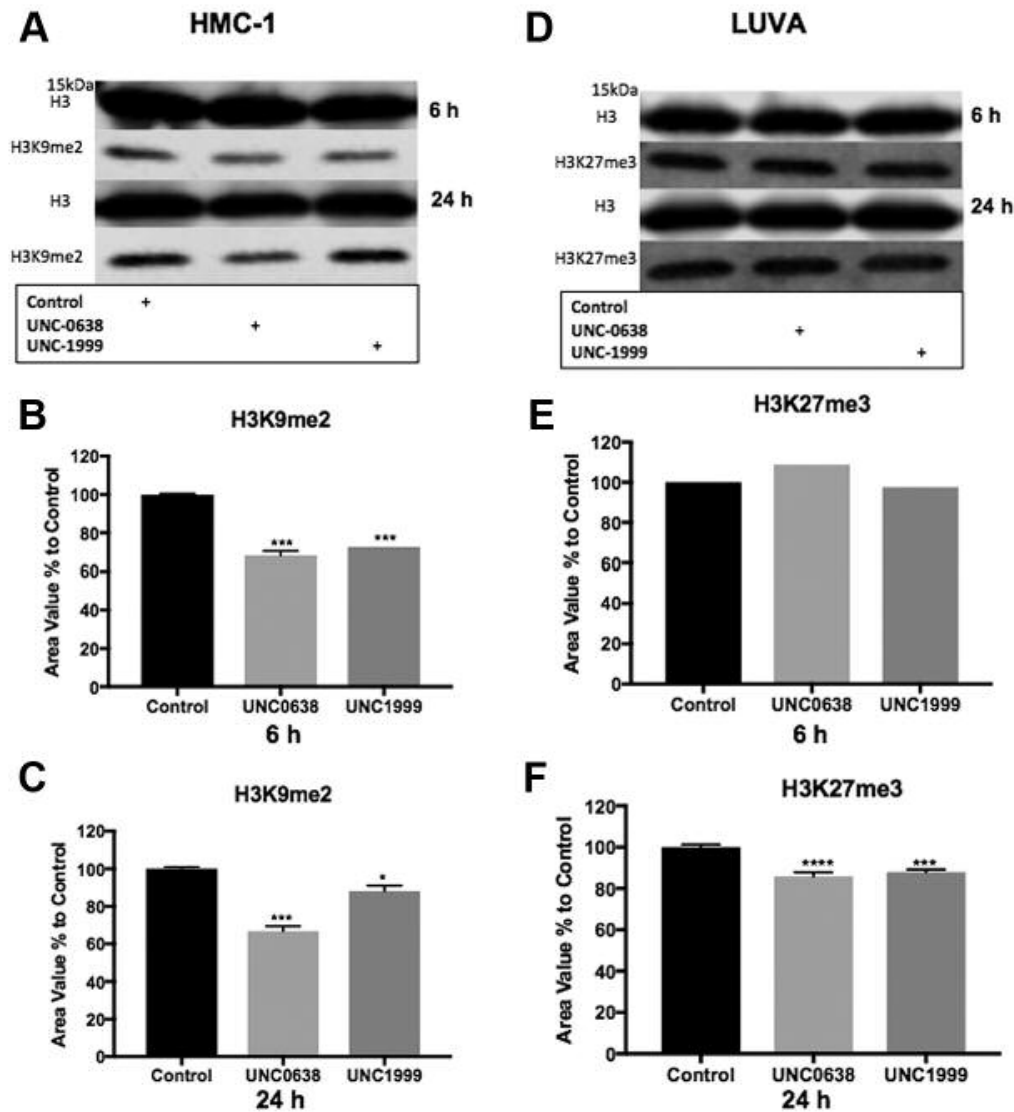

Figure 7. Histone methyltransferase inhibition causes reduced levels of H3K9me2 in HMC-1 cells and a reduction of H3K27me 3 in LUVA mast cells. (A) HMC-1 cells $\left(0.1 \times 10^{6} \mathrm{cells} / \mathrm{ml}\right)$ were incubated for the indicated time periods hours with UNC-0638 (5 $\left.\mu M\right)$ or UNC-1999 (5 $\left.\mu M\right)$, followed by Western blot analysis for the levels of the H3K9me 2 mark. Histone 3 (H3) was used as house-keeping control. (B-C) Quantification of H3K9me 2 levels by densitometry. (D) LUVA cells $(0.1 \times 106 \mathrm{cells} / \mathrm{ml})$ were incubated for the indicated time periods with UNC-0638 (5 $\mu M)$ or UNC-1999 (5 $\mu M)$, followed by Western blot analysis for the levels of the H3K9me2 mark. Histone 3 (H3) was used as house-keeping control. (E-F) Quantification of $H 3 K 9 m e 2$ levels by densitometry. Data are representative of three independent experiments and are given as mean values \pm SEM ( $n=3)$. * $p \leq 0.05$; $* * * p \leq 0.001 ; * * * * p \leq 0.0001$.

However, the majority of patients with aggressive systemic mastocytosis have a KITD816V mutation, which renders several approved tyrosine kinase inhibitors, such as nilotinib and imatinib, ineffective $(30,31)$. Currently, the approved drug for aggressive systemic mastocytosis is instead midostaurin, which is also a tyrosine kinase inhibitor (32). However, the efficacy of this drug in aggressive systemic mastocytosis is limited. For these reasons, mastocytosis can be a serious condition for which treatment options are still limited to the symptoms, and there is currently no curative therapy (4-6). Previous studies have suggested that epigenetic changes play important roles in treatment resistance and tumor progression $(33,34)$. Based on this, it has been evaluated whether inhibitors of histone-modifying enzymes, in particular HDAC inhibitors, can have tumorsuppressive properties. In line with this, it was recently demonstrated that transformed mast cells are sensitive to
HDAC inhibition (28). However, prior to this study, it was not known whether inhibition of histone-modifying enzymes beyond HDAC can suppress the growth/viability of transformed mast cells.

In this study we show that histone methyltransferase inhibitors (UNC-0638 and UNC-1999) cause significant and profound reductions in cell growth and viability of transformed human mast cells (HMC-1 and LUVA), in a time- and dose- dependent manner. In contrast, inhibition of histone demethylase or histone acetyltransferase activity did not alter cell viability. Further, treatment of HMC-1 cells with histone methyltransferase inhibitors resulted in a rapid and significant reduction of the H3K9me 2 mark after $6 \mathrm{~h}$ of treatment and this reduction persisted up to $24 \mathrm{~h}$. In contrast, a small but significant reduction of the H2K27me3 mark was observed only in LUVA cells after $24 \mathrm{~h}$ exposure to either of the histone methyltransferase inhibitors. 
The inhibition of the growth of transformed human mast cells (HMC-1 and LUVA) upon treatment with UNC-0638 or UNC-1999 introduces the novel notion that transformed mast cells are sensitive to histone methyltransferase inhibition. These results are consistent with previous studies showing that UNC-1999 is efficacious in different types of cancer, including leukemia, multiple myeloma, and colon cancer (35). UNC-1999 is known to inhibit enhancer of zeste homolog 2 (EZH2) and enhancer of zeste homolog1 (EZH1) lysine methyltransferases. These proteins are the catalytic components of the Polycomb Repressive Complex 2 (PRC2), which inhibits the target gene expression through methylation of histone 3 on lysine 27 (H3K27) (36). Our data are also in line with previous studies showing that inhibition of EZH2 by UNC1999 may reduce cancer cell proliferation and migration, induce apoptosis in bladder cancer cells and contribute to the regression of bladder tumor xenografts in mice (37). UNC-0638 is known to selectively and potently inhibit G9a and G9a-like protein (GLP) methyltransferase, an enzyme known to catalyze mono- and di-methylation of lysine 9 on histone 3 (38). Notably, overexpression of G9a is associated with metastasis and enhanced proliferation of a number of cancer cells $(39,40)$, and our data are thus consistent with this notion by showing that inhibition of this enzyme can reduce viability and growth of transformed mast cells.

Our data show that the $\mathrm{H} 3 \mathrm{~K} 9 \mathrm{me} 2$ mark was significantly reduced in HMC-1 cells treated with either UNC-0638 or UNC-1999. Since UNC-0638 is a selective inhibitor of G9a and GLP (38, 41-43), these findings suggest that G9a and/or GLP play a role in the generation of the H3K9me 2 mark in transformed mast cells, which is consistent with the known substrate specificity of G9a/GLP. UNC-1999, however, is known to be selective for inhibition of the histone methyltransferases EZH2/EZH1 (44), and it is thought that EZH2/EZH1 predominantly deposits methylation marks on H3K27. Since our findings reveal that UNC-1999 can also affect the $\mathrm{H} 3 \mathrm{~K} 9 \mathrm{me} 2$ mark, at least to a limited extent, this suggests that UNC-1999 may also target G9a and/or GLP. Overall, the cytotoxic effects of UNC-0638 and UNC-1999 on the transformed mast cells indicate that adequate histone methylation, e.g. at $\mathrm{H} 3 \mathrm{~K} 9$ or $\mathrm{H} 3 \mathrm{~K} 27$, is critical for their survival.

This study revealed that transformed mast cells exposed to both histone methyl transferase inhibitors underwent cell death associated with caspase- 3 activation. The induction of caspase-3 suggests cell death with characteristics of apoptosis, a type of cell death that is typically associated with DNA fragmentation induced by caspase activated DNAase (CAD) (45). However, histone methyltransferase inhibition did not induce detectable DNA fragmentation, either in HMC-1 or LUVA cells. Another typical feature of classical apoptosis is phosphatidyl serine exposure on the outer leaflet of the cell membrane, in the absence of cell membrane permeabilization. This is manifested by Annexin $\mathrm{V}$ positivity in the absence of positive staining with nuclear dyes (DRAQ7 in this study). However, single Annexin V+ cells were not observed after exposure of the transformed mast cells to the histone methyltransferase inhibitors. Altogether, these data suggest that the type of cell death induced in mast cells exposed to histone methyltransferase inhibitors differs from classical apoptosis.

Together, our findings introduce the novel notion that transformed mast cells are sensitive to histone methyltransferase inhibition. These findings may form the basis for a further evaluation of the clinical usefulness of histone methyltransferase inhibition for the treatment of conditions characterized by mast cell transformation, such as mastocytosis. We can also foresee the use of methyltransferase inhibition in malignant conditions where mast cells might have a pathogenic impact (46).

\section{Conflicts of Interest}

The Authors declare no conflicts of interest in relation to this work.

\section{Authors' Contributions}

SA planned and performed the experiments, and wrote the manuscript; FRM planned experiments, supervised the study and contributed to the writing of the manuscript; GP designed and planned the study, interpreted data and wrote the manuscript.

\section{Acknowledgements}

This work was supported by grants from: The Swedish Research Council, The Swedish Cancer Foundation, The Swedish Heart and Lung Foundation, Knut \& Alice Wallenberg Foundation and the Saudi Arabian Ministry of Education.

\section{References}

1 Pejler G, Ronnberg E, Waern I and Wernersson S: Mast cell proteases: Multifaceted regulators of inflammatory disease. Blood 115(24): 4981-4990, 2010. PMID: 20233968. DOI: 10.1182/blood-2010-01-257287

2 Wernersson S and Pejler G: Mast cell secretory granules: Armed for battle. Nat Rev Immunol 14(7): 478-494, 2014. PMID: 24903914. DOI: $10.1038 /$ nri3690

3 Voehringer D: Protective and pathological roles of mast cells and basophils. Nature reviews Immunology 13(5): 362-375, 2013. PMID: 23558889. DOI: $10.1038 /$ nri3427

4 Pardanani A: Systemic mastocytosis in adults: 2015 update on diagnosis, risk stratification, and management. Am J Hematol 90(3): 250-262, 2015. PMID: 25688753. DOI: 10.1002/ajh.23931

5 Arock M, Akin C, Hermine O and Valent P: Current treatment options in patients with mastocytosis: Status in 2015 and future perspectives. Eur J Haematol 94(6): 474-490, 2015. PMID: 25753531. DOI: $10.1111 /$ ejh.12544 
6 Valent P: Diagnosis and management of mastocytosis: An emerging challenge in applied hematology. Hematology Am Soc Hematol Educ Program 2015: 98-105, 2015. PMID: 25753531. DOI: 10.1182/asheducation-2015.1.98

7 Ustun C, Gotlib J, Popat U, Artz A, Litzow M, Reiter A, Nakamura R, Kluin-Nelemans HC, Verstovsek S, Gajewski J, Perales MA, George T, Shore T, Sperr W, Saber W, Kota V, Yavuz AS, Pullarkat V, Rogosheske J, Hogan W, Van Besien K, Hagglund H, Damaj G, Arock M, Horny HP, Metcalfe DD, Deeg HJ, Devine S, Weisdorf D, Akin C and Valent P: Consensus opinion on allogeneic hematopoietic cell transplantation in advanced systemic mastocytosis. Biol Blood Marrow Transplant 22(8): 1348-1356, 2016. PMID: 27131865. DOI: 10.1016/ j.bbmt.2016.04.018

8 Peschansky VJ and Wahlestedt C: Non-coding rnas as direct and indirect modulators of epigenetic regulation. Epigenetics 9(1): 3-12, 2014. PMID: 24739571. DOI: 10.4161/epi.27473

9 Reddy MA and Natarajan R: Recent developments in epigenetics of acute and chronic kidney diseases. Kidney Int 88(2): 250-261, 2015. PMID: 25993323. DOI: 10.1038/ki.2015.148

10 Susztak K: Understanding the epigenetic syntax for the genetic alphabet in the kidney. J Am Soc Nephrol 25(1): 10-17, 2014. PMID: 24179169. DOI: 10.1681/ASN.2013050461

11 Chen R, Kang R, Fan XG and Tang D: Release and activity of histone in diseases. Cell Death Dis 5: e1370, 2014. PMID: 25118930. DOI: $10.1038 /$ cddis.2014.337

12 Kouzarides T: Chromatin modifications and their function. Cell 128(4): 693-705, 2007. PMID: 17320507. DOI: 10.1016/ j.cell.2007.02.005

13 Strahl BD and Allis CD: The language of covalent histone modifications. Nature 403(6765): 41-45, 2000. PMID: 10638745. DOI: $10.1038 / 47412$

14 Greer EL and Shi Y: Histone methylation: A dynamic mark in health, disease and inheritance. Nat Rev Genet 13(5): 343-357, 2012. PMID: 22473383. DOI: $10.1038 / \mathrm{nrg} 3173$

15 Bedford MT and Richard S: Arginine methylation an emerging regulator of protein function. Mol Cell 18(3): 263-272, 2005. PMID: 15866169. DOI: 10.1016/j.molcel.2005.04.003

16 Li B, Carey M and Workman JL: The role of chromatin during transcription. Cell 128(4): 707-719, 2007. PMID: 17320508. DOI: 10.1016/j.cell.2007.01.015

17 Sims RJ, 3rd, Nishioka K and Reinberg D: Histone lysine methylation: A signature for chromatin function. Trends Genet 19(11): 629-639, 2003. PMID: 14585615. DOI: 10.1016/ j.tig.2003.09.007

18 Fong $\mathrm{CY}$, Morison $\mathrm{J}$ and Dawson MA: Epigenetics in the hematologic malignancies. Haematologica 99(12): 1772-1783, 2014. PMID: 25472952. DOI: 10.3324/haematol.2013.092007

19 Itzykson R and Fenaux P: Epigenetics of myelodysplastic syndromes. Leukemia 28(3): 497-506, 2014. PMID: 24247656. DOI: $10.1038 / \mathrm{leu} .2013 .343$

20 Shih AH, Abdel-Wahab O, Patel JP and Levine RL: The role of mutations in epigenetic regulators in myeloid malignancies. Nat Rev Cancer 12(9): 599-612, 2012. PMID: 22898539. DOI: $10.1038 / \mathrm{nrc} 3343$

21 Schwaab J, Schnittger S, Sotlar K, Walz C, Fabarius A, Pfirrmann M, Kohlmann A, Grossmann V, Meggendorfer M, Horny HP, Valent P, Jawhar M, Teichmann M, Metzgeroth G, Erben P, Ernst T, Hochhaus A, Haferlach T, Hofmann WK, Cross $\mathrm{NC}$ and Reiter A: Comprehensive mutational profiling in advanced systemic mastocytosis. Blood 122(14): 2460-2466, 2013. PMID: 23958953. DOI: 10.1182/blood-2013-04-496448

22 Soucie E, Brenet F and Dubreuil P: Molecular basis of mast cell disease. Mol Immunol 63(1): 55-60, 2015. PMID: 24768320. DOI: $10.1016 /$ j.molimm.2014.03.013

23 Hanssens K, Brenet F, Agopian J, Georgin-Lavialle S, Damaj G, Cabaret L, Chandesris MO, de Sepulveda P, Hermine O, Dubreuil P and Soucie E: Srsf2-p95 hotspot mutation is highly associated with advanced forms of mastocytosis and mutations in epigenetic regulator genes. Haematologica 99(5): 830-835, 2014. PMID: 24389310. DOI: 10.3324/haematol.2013.095133

24 Jawhar M, Schwaab J, Schnittger S, Meggendorfer M, Pfirrmann M, Sotlar K, Horny HP, Metzgeroth G, Kluger S, Naumann N, Haferlach C, Haferlach T, Valent P, Hofmann WK, Fabarius A, Cross NC and Reiter A: Additional mutations in srsf2, asxl1 and/or runx 1 identify a high-risk group of patients with kit $\mathrm{d} 816 \mathrm{v}(+)$ advanced systemic mastocytosis. Leukemia 30(1): 136-143, 2016. PMID: 26464169. DOI: 10.1038/leu.2015.284

25 Jawhar M, Schwaab J, Schnittger S, Sotlar K, Horny HP, Metzgeroth G, Muller N, Schneider S, Naumann N, Walz C, Haferlach T, Valent P, Hofmann WK, Cross NC, Fabarius A and Reiter A: Molecular profiling of myeloid progenitor cells in multi-mutated advanced systemic mastocytosis identifies kit $\mathrm{d} 816 \mathrm{v}$ as a distinct and late event. Leukemia 29(5): 1115-1122, 2015. PMID: 25567135. DOI: 10.1038/leu.2015.4

26 Soucie E, Hanssens K, Mercher T, Georgin-Lavialle S, Damaj G, Livideanu C, Chandesris MO, Acin Y, Letard S, de Sepulveda $\mathrm{P}$, Hermine O, Bernard OA and Dubreuil P: In aggressive forms of mastocytosis, tet2 loss cooperates with c-kitd816v to transform mast cells. Blood 120(24): 4846-4849, 2012. PMID: 23074272. DOI: 10.1182/blood-2011-12-397588

27 West AC and Johnstone RW: New and emerging hdac inhibitors for cancer treatment. J Clin Invest 124(1): 30-39, 2014. PMID: 24382387. DOI: $10.1172 /$ JCI69738

28 Lyberg K, Ali HA, Grootens J, Kjellander M, Tirfing M, Arock $\mathrm{M}$, Hagglund $\mathrm{H}$, Nilsson $\mathrm{G}$ and Ungerstedt $\mathrm{J}$ : Histone deacetylase inhibitor saha mediates mast cell death and epigenetic silencing of constitutively active $\mathrm{d} 816 \mathrm{v}$ kit in systemic mastocytosis. Oncotarget 8(6): 9647-9659, 2017. PMID: 28038453. DOI: 10.18632/oncotarget.14181

29 Rönnberg E and Pejler G: Serglycin: The master of the mast cell. Methods Mol Biol 836: 201-217, 2012. PMID: 22252637. DOI: 10.1007/978-1-61779-498-8_14

30 Ma Y, Zeng S, Metcalfe DD, Akin C, Dimitrijevic S, Butterfield $\mathrm{JH}$, McMahon G and Longley BJ: The c-kit mutation causing human mastocytosis is resistant to sti571 and other kit kinase inhibitors; kinases with enzymatic site mutations show different inhibitor sensitivity profiles than wild-type kinases and those with regulatory-type mutations. Blood 99(5): 1741-1744, 2002. PMID: 11861291. DOI: 10.1182/blood.v99.5.1741

31 Frost MJ, Ferrao PT, Hughes TP and Ashman LK: Juxtamembrane mutant v560gkit is more sensitive to imatinib (sti571) compared with wild-type c-kit whereas the kinase domain mutant d816vkit is resistant. Mol Cancer Ther 1(12): 1115-1124, 2002. PMID: 12481435.

32 Gotlib J, Kluin-Nelemans HC, George TI, Akin C, Sotlar K, Hermine O, Awan FT, Hexner E, Mauro MJ, Sternberg DW, Villeneuve M, Huntsman Labed A, Stanek EJ, Hartmann K, Horny HP, Valent $\mathrm{P}$ and Reiter A: Efficacy and safety of midostaurin in advanced systemic mastocytosis. N Engl J Med 
374(26): 2530-2541, 2016. PMID: 27355533. DOI: $10.1056 /$ NEJMoa1513098

33 Wilting $\mathrm{RH}$ and Dannenberg JH: Epigenetic mechanisms in tumorigenesis, tumor cell heterogeneity and drug resistance. Drug Resist Updat 15(1-2): 21-38, 2012. PMID: 22356866. DOI: $10.1016 /$ j.drup.2012.01.008

34 Egger G, Liang G, Aparicio A and Jones PA: Epigenetics in human disease and prospects for epigenetic therapy. Nature 429(6990): 457-463, 2004. PMID: 15164071. DOI: 10.1038/nature02625

35 Boudreaux SP, Ramirez-Herrick AM, Duren RP and Conneely OM: Genome-wide profiling reveals transcriptional repression of myc as a core component of nr4a tumor suppression in acute myeloid leukemia. Oncogenesis 1: e19, 2012. PMID: 23552735. DOI: $10.1038 /$ oncsis.2012.19

36 Cao R, Wang L, Wang H, Xia L, Erdjument-Bromage H, Tempst $\mathrm{P}$, Jones RS and Zhang Y: Role of histone h3 lysine 27 methylation in polycomb-group silencing. Science 298(5595): 1039-1043, 2002. PMID: 12351676. DOI: 10.1126/science.1076997

37 Chen Z, Du Y, Liu X, Chen H, Weng X, Guo J, Wang M, Wang $\mathrm{X}$ and Wang L: Ezh2 inhibition suppresses bladder cancer cell growth and metastasis via the jak2/stat 3 signaling pathway. Oncol Lett 18(1): 907-915, 2019. PMID: 31289569. DOI: 10.3892/ol.2019.10359

38 Vedadi M, Barsyte-Lovejoy D, Liu F, Rival-Gervier S, AllaliHassani A, Labrie V, Wigle TJ, Dimaggio PA, Wasney GA, Siarheyeva A, Dong A, Tempel W, Wang SC, Chen X, Chau I, Mangano TJ, Huang XP, Simpson CD, Pattenden SG, Norris JL, Kireev DB, Tripathy A, Edwards A, Roth BL, Janzen WP, Garcia BA, Petronis A, Ellis J, Brown PJ, Frye SV, Arrowsmith CH and Jin J: A chemical probe selectively inhibits g9a and glp methyltransferase activity in cells. Nat Chem Biol 7(8): 566-574, 2011. PMID: 21743462. DOI: 10.1038/nchembio.599

39 Cho HS, Kelly JD, Hayami S, Toyokawa G, Takawa M, Yoshimatsu M, Tsunoda T, Field HI, Neal DE, Ponder BA, Nakamura $\mathrm{Y}$ and Hamamoto R: Enhanced expression of ehmt2 is involved in the proliferation of cancer cells through negative regulation of siah1. Neoplasia 13(8): 676-684, 2011. PMID: 21847359. DOI: $10.1593 /$ neo. 11512

40 Hua KT, Wang MY, Chen MW, Wei LH, Chen CK, Ko CH, Jeng YM, Sung PL, Jan YH, Hsiao M, Kuo ML and Yen ML: The h3k9 methyltransferase $\mathrm{g} 9 \mathrm{a}$ is a marker of aggressive ovarian cancer that promotes peritoneal metastasis. Mol Cancer 13: 189, 2014. PMID: 25115793. DOI: 10.1186/1476-4598-13-189
41 Tachibana M, Sugimoto K, Fukushima T and Shinkai Y: Set domain-containing protein, $\mathrm{g} 9 \mathrm{a}$, is a novel lysine-preferring mammalian histone methyltransferase with hyperactivity and specific selectivity to lysines 9 and 27 of histone h3. J Biol Chem 276(27): 25309-25317, 2001. PMID: 11316813. DOI: 10.1074/jbc.M101914200

42 Collins RE, Tachibana M, Tamaru H, Smith KM, Jia D, Zhang $X$, Selker EU, Shinkai $Y$ and Cheng $X$ : In vitro and in vivo analyses of a phe/tyr switch controlling product specificity of histone lysine methyltransferases. J Biol Chem 280(7): 55635570, 2005. PMID: 15590646. DOI: $10.1074 / \mathrm{jbc} . M 410483200$

43 Kubicek S, O’Sullivan RJ, August EM, Hickey ER, Zhang Q, Teodoro ML, Rea S, Mechtler K, Kowalski JA, Homon CA, Kelly $\mathrm{TA}$ and Jenuwein T: Reversal of h3k9me2 by a small-molecule inhibitor for the g9a histone methyltransferase. Mol Cell 25(3): 473481, 2007. PMID: 17289593. DOI: 10.1016/j.molcel.2007.01.017

44 Konze KD, Ma A, Li F, Barsyte-Lovejoy D, Parton T, Macnevin CJ, Liu F, Gao C, Huang XP, Kuznetsova E, Rougie M, Jiang A, Pattenden SG, Norris JL, James LI, Roth BL, Brown PJ, Frye $\mathrm{SV}$, Arrowsmith CH, Hahn KM, Wang GG, Vedadi M and Jin J: An orally bioavailable chemical probe of the lysine methyltransferases ezh2 and ezh1. ACS Chem Biol 8(6): 13241334, 2013. PMID: 23614352. DOI: $10.1021 / \mathrm{cb} 400133 \mathrm{j}$

45 Wyllie AH: Glucocorticoid-induced thymocyte apoptosis is associated with endogenous endonuclease activation. Nature 284(5756): 555-556, 1980. PMID: 6245367. DOI: 10.1038/284 $555 \mathrm{a} 0$

46 Faustino-Rocha AI, Gama A, Neuparth MJ, Oliveira PA, Ferreira $\mathrm{R}$ and Ginja M: Mast cells in mammary carcinogenesis: Host or tumor supporters? Anticancer Res 37(3): 1013-1021, 2017. PMID: 28314259. DOI: 10.21873/anticanres.11411

Received March 16, 2020

Revised March 25, 2020

Accepted March 28, 2020 